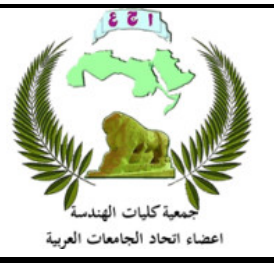

\title{
Numerical Study on the Performance and Behavior of Two-way Reinforced Concrete Slabs with Different Types of Styropor Blocks
}

\author{
Rand Tariq Kanaan ${ }^{1, *}$, and Ali Hussein Ali Al-Ahmed ${ }^{2}$ \\ ${ }^{1}$ Department of Civil Engineering, University of Baghdad, Baghdad, Iraq, rand93tariq@gmail.com \\ ${ }^{2}$ Department of Civil Engineering, University of Baghdad, Baghdad, Iraq, ali_hussein_alahmed@yahoo.co.uk \\ * Corresponding author: Rand Tariq Kanaan, rand93tariq@gmail.com \\ Published online: 31 March 2019
}

Abstract- This paper studies the performance of two-way reinforced concrete slabs with different sizesand shapes of cavities numerically under uniform load. Nineteen simply supported slab models were modeled with dimensions of $(1060 \times 1060 \times 70) \mathrm{mm}$. One of them wasthe reference model which was solid slab and the others were with different shapes, sizes and numbers of cavities.The slab models with cavities divided into three groupsaccording to the shape of the cavities, each group contained six slab models, first group contained slab models with square shape of cavities while the second group contained the models with diamond cavities and third group contained models with circular cavities.In each group there were different numbers of cavities $(9,16$ and 25), and the thickness was either $2 \mathrm{~cm}$ or $4 \mathrm{~cm}$.

The numerical results show that, when the percentage reduction of models weight was $(14 \%)$ which is corresponding to the cavities thickness of $(2 \mathrm{~cm})$, for this case the ultimate load capacity reduced by $(3.40$ $13.61) \%$. While when the percentage reduction in weight was $(28 \%)$ which is corresponding with the cavities thickness of $(2 \mathrm{~cm})$, the ultimate load capacity reduced by $(14.97-24.49) \%$.

Keywords- Cavities, Hollow slab, styropor block, Two-way slab, weight reduction.

\section{Introduction}

One of the most important handicaps of concrete constructions, in case of slabs, is the heavy weight of concrete which limits the span. Hence, many researchers had focused on solving this problem by reducing the selfweight of slabs, either by using light weight concrete which is achieved by using light weight aggregate or porous materials which produced micro voids inside the concrete[7], [9], or making changes in the geometry of cross section area of the slab by using voided slabs.[6]

Voided slabs (hollow slabs) are reinforced concrete slabs in which some of concrete is removed to form voids in order to reduce weight. The aims of using voids are to remove concrete from the tension zone because it is not effective, this leads to reduce the self-weight of the slab so reducing the dead load and reduce the steel reinforcement.[3], [8] In the other hand, voided slabs increasing the temperature and sound isolation properties so decreasing the air-conditioning and sound isolation costs.
There are a number of ways to reduce the self-weight of buildings. One of them is by using the hollow core slabs.

The current research presents a numerical study about the performance and behavior of two-way reinforced concrete slabs with different shapes and sizes of cavities, using ANSYS 17.1 software

\section{The Numerical Analysis}

Finite elements approach passing by steps starting from creating defined elements, real constants of each element if required, materials model, key points, lines, areas and then volume to create the whole geometry of the problem. In the most of (FEA) software, nodal, element solutions are available to present the whole solution of the problem, so that it is easy to determine any unknown parameter and plot it graphically.[4] 


\subsection{Details of models}

The work of this study includes modeling nineteen slab models with same dimensions $(1060,1060,70) \mathrm{mm}$, one of them is solid slab model and the others are with cavities. The slab models are simply supported two way slabs with minimum reinforcement of $(\varnothing 10 @ 100 \mathrm{~mm})$ at the bottom of slab specimens according to the ACI Code (Article 8.6.1 ACI-318 code) [1] and $10 \mathrm{~mm}$ concrete cover. The slab models are divided into three groups according to the shape of cavities, each group contains six models with different number and thickness of cavities. First group contains models with square cavities; second group contains models with diamond cavities and third group of models with circular cavities. The thickness of cavities either $2 \mathrm{~cm}$ or $4 \mathrm{~cm}$, and the number of cavities in each group are 25, 16 or 9, as shown in Table. 1.

For each thickness of cavities $(2 \mathrm{~cm}$ or $4 \mathrm{~cm})$ the volume of cavities to the volume of slab is constant value, i.e. for the specific thickness of cavities with different shape (square, diamond or circle) and different number $(25,16$ or 9) the volume of cavities is constant.

Table 1: The details of slab models

\begin{tabular}{c|ccc}
\hline Groups & $\begin{array}{c}\text { Slab } \\
\text { models }\end{array}$ & $\begin{array}{c}\text { Number } \\
\text { of } \\
\text { Cavities }\end{array}$ & $\begin{array}{c}\text { Dimension of } \\
\text { Cavities } \\
\text { (mm) }\end{array}$ \\
\hline \multirow{5}{*}{ Group } & Solid & 0 & - \\
1 & S-25-2 & 25 & $140 \times 140 \times 20$ \\
& S-25-4 & 25 & $140 \times 140 \times 40$ \\
& S-16-2 & 16 & $175 \times 175 \times 20$ \\
& S-16-4 & 16 & $175 \times 175 \times 40$ \\
Group & S-9-2 & 9 & $233.33 \times 233.33 \times 20$ \\
$\mathbf{2}$ & S-9-4 & 9 & $233.33 \times 233.33 \times 40$ \\
& D-25-2 & 25 & $140 \times 140 \times 20$ \\
& D-25-4 & 25 & $140 \times 140 \times 40$ \\
& D-16-2 & 16 & $175 \times 175 \times 20$ \\
& D-16-4 & 16 & $175 \times 175 \times 40$ \\
& D-9-2 & 9 & $233.33 \times 233.33 \times 20$ \\
Group & D-9-4 & 9 & $233.33 \times 233.33 \times 40$ \\
3 & C-25-2 & 25 & $157.97 \times 20 *$ \\
& C-25-4 & 25 & $157.97 \times 40$ \\
& C-16-2 & 16 & $197.5 \times 20$ \\
& C-16-4 & 16 & $197.5 \times 40$ \\
& C-9-2 & 9 & $263.3 \times 20$ \\
& C-9-4 & 9 & $263.3 \times 40$ \\
\hline
\end{tabular}

*First number refers to diameter of the cavity and second number refers to the thickness

\subsection{Modeling}

Mechanical APDL ANSYS 17.1 software was used to create the models of the current study.

\section{- Element types}

The modeling of concrete was produced by using SOLID65 element. This element contains 8 nodes, each one of them of 3 degrees of freedom: nodal translation in $\mathrm{x}-, \mathrm{y}-$, and $\mathrm{z}-$ direction. This element was chose to represent the concrete material because of its capability of cracking when it subjects to tension, crushing when it subjects to compression, and plastic deformation [2]. The geometry of SOLID65 element is shown in Fig.1.

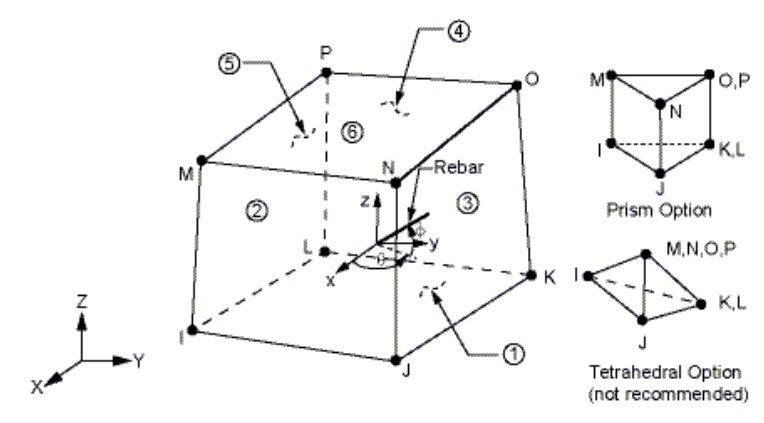

Figure 1: SOLID65 Geometry [2]

LINK180 element that shown in Fig. 2 was used to simulate the behavior of the steel rebars, it is a three dimensional spar element of 2 nodes, each of 3translational degrees of freedom in $\mathrm{x}-, \mathrm{y}-$, and $\mathrm{z}$ - direction. LINK180 resists only axial forces.[2]
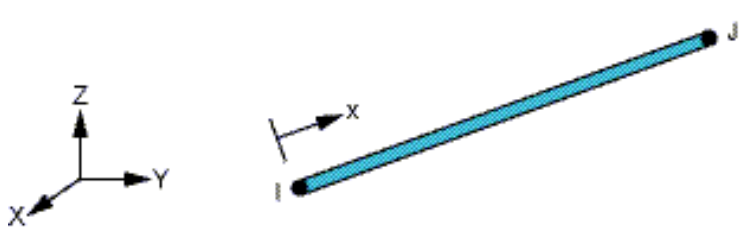

Figure 2: LINK180 geometry [2]

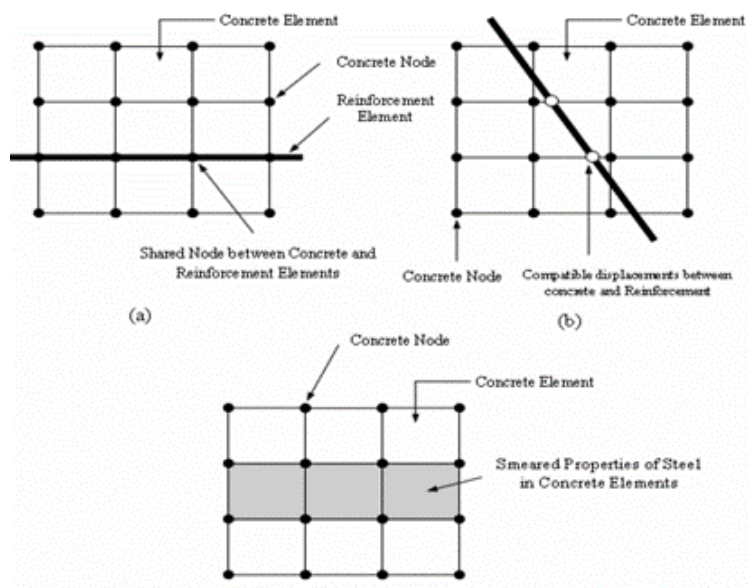

Figure 3: Models for reinforcement in reinforced concrete [5]

\section{Main Reinforcement Modeling}

Discrete representation of main reinforcements as matched the actual reinforcement of concrete slabs was adopted. Discrete representation is broadly used to represent the reinforcement bars. Here, the reinforcement modeled as discrete technique which is linked to the nodes of concrete 
mesh, so that, the meshes of concrete and the rebars have a shared nodes and occupied regions. The discrete model of representation of reinforcement has a number of benefits, one of them; it offers a full compatibility of displacement between rebars and concrete. One of its disadvantages, is it restrict the mesh and it is required a larger number of the total elements. Fig.3 showed the three types of steel reinforcement representation.[5]

\subsection{Real constants and material properties}

Real constants and the properties of the used materials for all elements were inserted, such as, Young's modulus, Poisson's ratio, compressive and tensile strengths, open and close shear transfer coefficients (for concrete), for the steel reinforcement needs only Poisson's ratio and modulus of elasticity for linear analysis.

The model in (FEA) by ANSYS computer program is able for forecasting the concrete failure and other components materials. In concrete, both failure modes (cracking and crushing) are taken into account. The FEM adopts a smeared cracking approach to simulate the reinforced concrete. In this approach, concrete cracking happens when the principal tensile stress exceeds the maximum tensile strength based on the (ACI - 318-2014) [1]. The Young's modulus of the material is assumed to be zero in the parallel direction to the principal tensile stress direction that is mean the concrete not capable to resists tensile strength more than limit and the modulus of elasticity in tension equal to zero.

Crushing of the concrete at the compression zone of the slab model develops in case the interior stresses passed the concrete compressive strength so that the crush will begin. In the present research, the ability of crushing was switched off and the concrete cracking controlled the finite element models failure and the plastic hinge develop up to failure because concrete is a brittle material so that there is no translation zone between elastic and plastic stage. [2]

\subsection{Modeling and meshing}

The concrete slab was modeled as volumes. All volumes were divided with each other using work-planes in order to make all the nodes of each volume coincide with the nodes of the other volumes, all the cavities were inserted, and their shapes and dimensions were taken in to account as shown in Fig.4. The steel reinforcement in both directions was created as lines then saved in a component for simplicity of meshing process. All the volumes had meshed. The specimens that contains square cavities had meshed with cubic elements of $10 \mathrm{~cm}$ edge length (uniform mesh), while the specimens that contains diamond and circular cavities had meshed by (free mesh) option, as it is shown in the Fig. 4. The lines of reinforcement bars also meshed with $10 \mathrm{~cm}$ element length. The proper mesh attributes were given to each element.

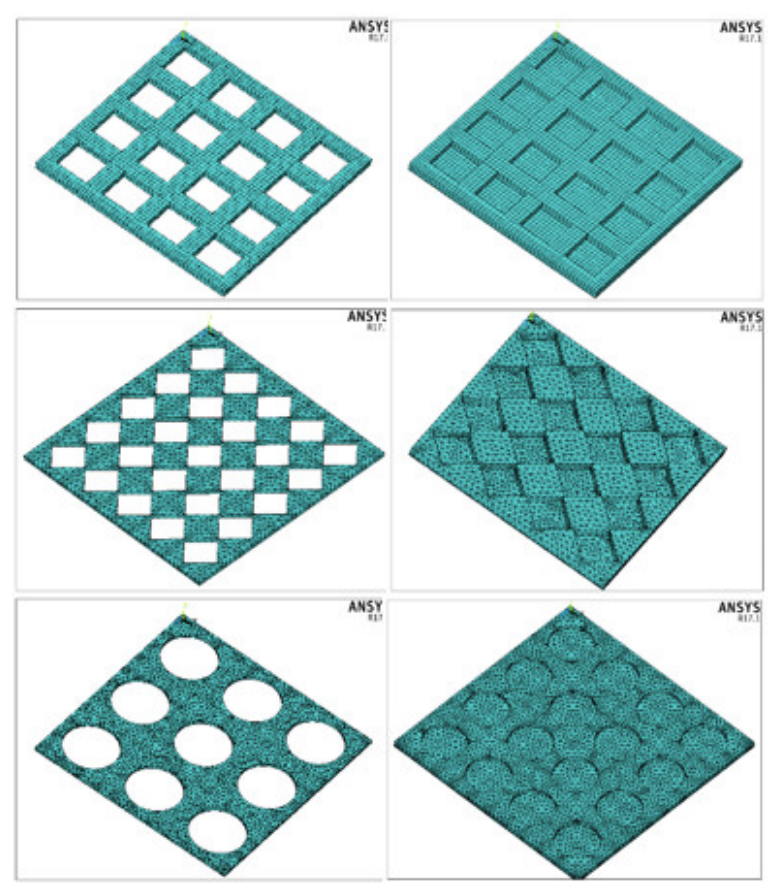

Figure 4: Meshed volumes for some specimens

\subsection{Loading, boundary conditions, analysis type and solution control options}

The boundary conditions should be applied for any structure to obtain a unique solution. The bottom nodes that located on the line which is on $3 \mathrm{~cm}$ distance from the outer side edges of the slabs were constrained to simulate the simple support condition where two of them were restricted in $\mathrm{x}_{-}, \mathrm{y}_{-}$, and $\mathrm{z}-$ direction to simulate the hinge supports, while the other two shafts were restricted in $\mathrm{x}$-, $\mathrm{y}-$ and $\mathrm{z}-, \mathrm{y}$ - directions respectively, to be the rollers, as shown in Fig.5. Load was applied as a pressure on the top area of concrete slab as shown in Fig.6.

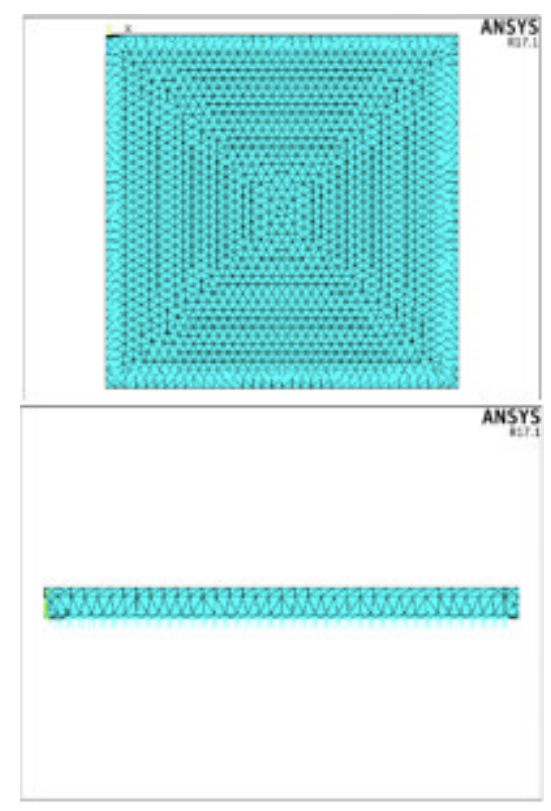

Figure 5: Boundary conditions of supports. 


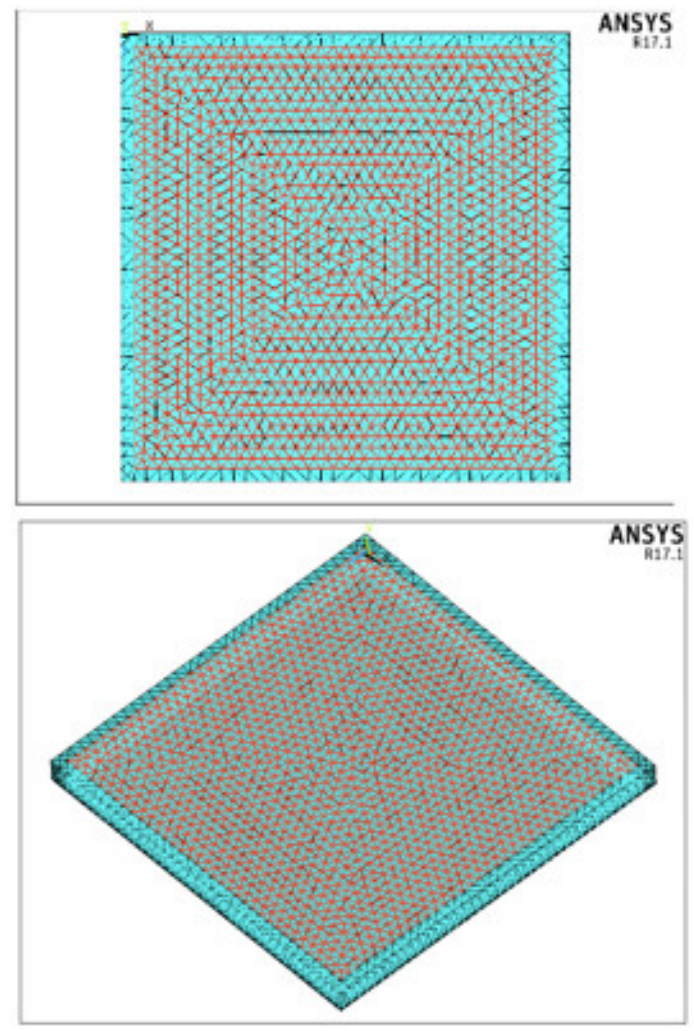

Figure 6: The applied loading

The applied loading based on the strength capacity from experimental tests. In static loading, the following assumptions were made:

1. All materials (concrete, steel reinforcements) behaved as isotropic and homogeneous.

2. Plane sections remain plane before and after applied loading.

3. Full bond between all materials.

4. Self-weight of the slab was ignored.

All dimensions and material properties as actual and from experimental tests.

First of all, model under uniform loading was simulates and the results were obtained. The applied uniform loading is similar to that in experimental tests as ultimate loading.

The Newton-Raphson analysis method was adopted to solve the equations. The load was divided into steps and applied incrementally till the failure occurred. The displacement control with tolerance of $(5 \%)$ was adapted to convergence the results.

\section{Numerical Results}

\subsection{First crack load}

It was noticed that, first cracking load for models of first group (slab models with square cavities) was the lowest while higher for the models of second group (slab models with diamond cavities) as shown in Table 2. This table also shows the percentage of first cracking load to ultimate load capacity for each specimen.

Table 2: First cracking load

\begin{tabular}{|c|c|c|c|c|}
\hline & Specimens & $\begin{array}{c}\text { First } \\
\text { cracking } \\
\text { load } \\
\left(\mathrm{kN} / \mathrm{m}^{2}\right)\end{array}$ & $\begin{array}{l}\text { Ultimate } \\
\text { load } \\
\text { capacity } \\
\left(\mathrm{kN} / \mathrm{m}^{2}\right)\end{array}$ & $\begin{array}{l}\text { Percentage of } \\
\text { first cracking } \\
\text { load to } \\
\text { ultimate load } \\
\text { capacity }(\%)\end{array}$ \\
\hline & Solid & 25 & 147 & 17 \\
\hline \multirow{6}{*}{$\begin{array}{c}\text { Group } \\
1\end{array}$} & $\mathrm{~S}-25-2$ & 16 & 136 & 11.76 \\
\hline & S-25-4 & 15 & 119 & 12.61 \\
\hline & S-16-2 & 15 & 131 & 11.45 \\
\hline & S-16-4 & 14 & 115 & 12.17 \\
\hline & S-9-2 & 15 & 127 & 11.81 \\
\hline & S-9-4 & 14 & 111 & 12.61 \\
\hline \multirow{6}{*}{$\begin{array}{c}\text { Group } \\
2\end{array}$} & D-25-2 & 22 & 142 & 15.49 \\
\hline & D-25-4 & 21 & 125 & 16.8 \\
\hline & D-16-2 & 22 & 137 & 16.06 \\
\hline & D-16-4 & 21 & 121 & 17.36 \\
\hline & D-9-2 & 21 & 131 & 16.03 \\
\hline & D-9-4 & 20 & 118 & 17.8 \\
\hline \multirow{6}{*}{$\begin{array}{c}\text { Group } \\
\mathbf{3}\end{array}$} & C-25-2 & 18 & 139 & 12.95 \\
\hline & C-25-4 & 17 & 123 & 13.82 \\
\hline & C-16-2 & 17 & 134 & 12.69 \\
\hline & C-16-4 & 17 & 118 & 14.41 \\
\hline & C-9-2 & 16 & 129 & 12.4 \\
\hline & C-9-4 & 16 & 114 & 14.04 \\
\hline
\end{tabular}

\subsection{Load-Deflection behavior}

Table.3 shows the ultimate load capacity and ultimate deflection for each specimen. The load-deflection behavior is explained for each specimen of each group as shown in Figs.7, 8 and 9.

In general, the load - central deflection behavior for all slab models show the same trend, three stages of load central deflection can be noticed from curves.

First stage shows linear behavior of load-central deflection relationships. This stage extends from zero loading to the first cracking load. In this stage no cracks occur in slab models and the materials are still elastic.

Second stage shows the changing of the behavior of loadcentral deflection from linearity to nonlinearity because the rate of deflection increasing is continuously increases as the load is increased.

In third stage, the behavior of load-central deflection curves changes completely from linear to nonlinear behavior, because when the applied load approaches to its ultimate value, the increasing rate in deflection is constitutively exceeds the increasing rate of applied load. 
Table 3: Ultimate load capacity and ultimate deflection

\begin{tabular}{|c|c|c|c|c|c|c|}
\hline & $\begin{array}{l}\frac{n}{0} \\
\frac{0}{0} \\
\Sigma\end{array}$ & $\stackrel{*}{\stackrel{*}{2}}$ & 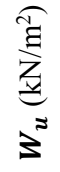 & 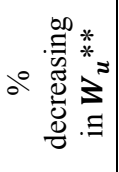 & $\approx \underset{\nabla}{\stackrel{\overbrace I}{Z}}$ & 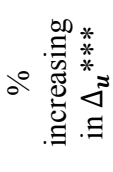 \\
\hline & Solid & - & 147 & - & 20.75 & - \\
\hline \multirow{6}{*}{$\begin{array}{c}\text { Group } \\
1\end{array}$} & S-25-2 & 14 & 136 & 7.48 & 22.71 & 9.45 \\
\hline & S-25-4 & 28 & 119 & 19.01 & 24.94 & 20.19 \\
\hline & S-16-2 & 14 & 131 & 10.88 & 22.78 & 9.78 \\
\hline & S-16-4 & 28 & 115 & 21.77 & 25.07 & 20.82 \\
\hline & S-9-2 & 14 & 127 & 13.61 & 22.96 & 10.65 \\
\hline & S-9-4 & 28 & 111 & 24.29 & 25.14 & 21.16 \\
\hline \multirow{6}{*}{$\begin{array}{c}\text { Group } \\
2\end{array}$} & D-25-2 & 14 & 142 & 3.40 & 22.19 & 6.94 \\
\hline & D-25-4 & 28 & 125 & 14.97 & 24.41 & 17.64 \\
\hline & D-16-2 & 14 & 137 & 6.80 & 22.37 & 7.81 \\
\hline & D-16-4 & 28 & 121 & 17.69 & 24.62 & 18.65 \\
\hline & D-9-2 & 14 & 131 & 10.88 & 22.54 & 8.63 \\
\hline & D-9-4 & 28 & 118 & 19.73 & 24.85 & 19.76 \\
\hline \multirow{6}{*}{$\begin{array}{c}\text { Group } \\
3\end{array}$} & C-25-2 & 14 & 139 & 5.44 & 22.42 & 8.05 \\
\hline & C-25-4 & 28 & 123 & 16.33 & 24.63 & 18.7 \\
\hline & C-16-2 & 14 & 134 & 8.84 & 22.61 & 8.96 \\
\hline & C-16-4 & 28 & 118 & 19.73 & 24.75 & 19.28 \\
\hline & C-9-2 & 14 & 129 & 12.24 & 22.83 & 10.02 \\
\hline & C-9-4 & 28 & 114 & 22.45 & 24.94 & 20.19 \\
\hline
\end{tabular}

*\% R: is the percentage decreasing in slab weight with respect to solid specimen.

$* * \%$ decreasing $=\frac{W_{(\text {slab with cavities })}-W_{(\text {Solid slab })}}{W_{(\text {Solid slab })}} \times 100$

$* * * \%$ increasing $=\frac{\Delta_{(\text {slab with cavities })}-\Delta_{(\text {Solid slab })}}{\Delta_{(\text {Solid slab })}} \times 100$

\section{Group 1}

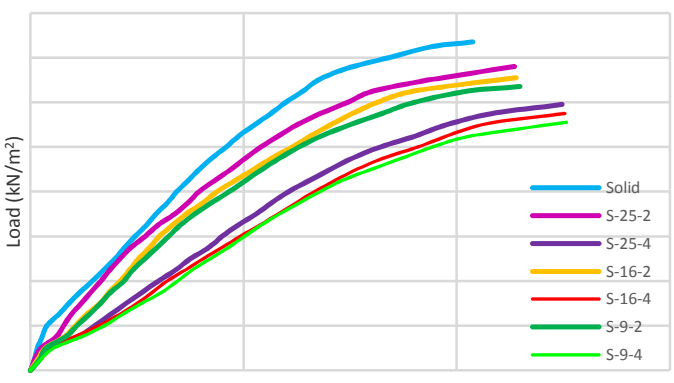

Central deflection $(\mathrm{mm})$

Figure 7: Load-deflection relationship for slabs of Group 1 (slabs with square cavities)
Group 3

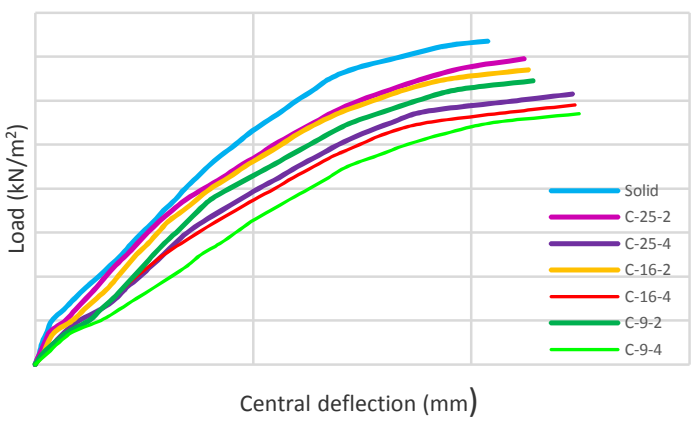

Figure 8: Load-deflection relationship for slabs of Group 2 (slabs with diamond cavities)

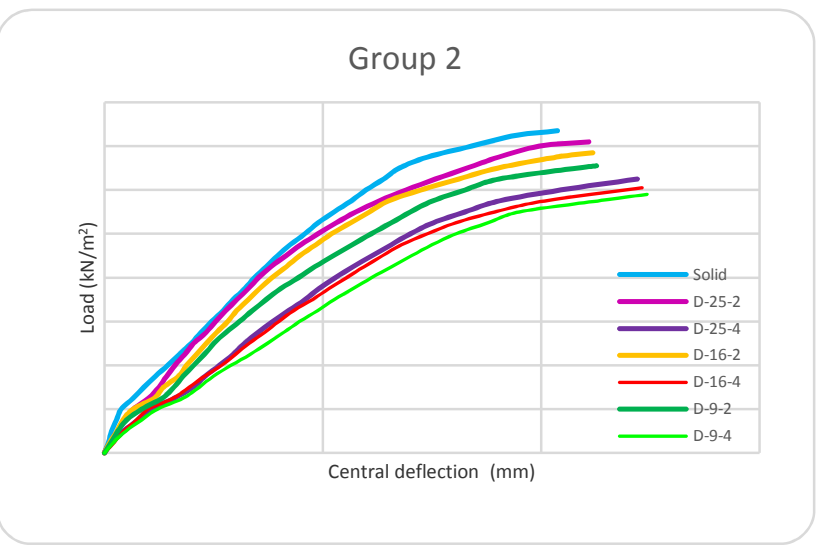

Figure 9: Load-deflection relationship for slabs of Group 3 (slabs with circular cavities)

\subsubsection{Effect of thickness of cavities on the load- deflection behavior}

The load - central deflection relationships for models that have same number of cavities and different thickness of cavities were showed in Figs. 10, 11 and 12. From these figures, it was noticed that the ultimate deflection of models of $2 \mathrm{~cm}$ cavity thickness is lower than of $4 \mathrm{~cm}$ cavity thickness, and all models have ultimate load capacity lower than the solid slab model. However, for same number of cavities as the thickness of cavity was increased the ultimate load capacity was decreased and the ultimate deflection was increased.

Table 4 shows the percentages decreasing in loads for slab models having constant number of cavities with different thickness compared to ultimate load of the solid slab model corresponding to deflection level of the solid slab model. While, Table 5 shows the deflection for same slabs corresponding to ultimate load level of slabs having $4 \mathrm{~cm}$ cavity thickness. 

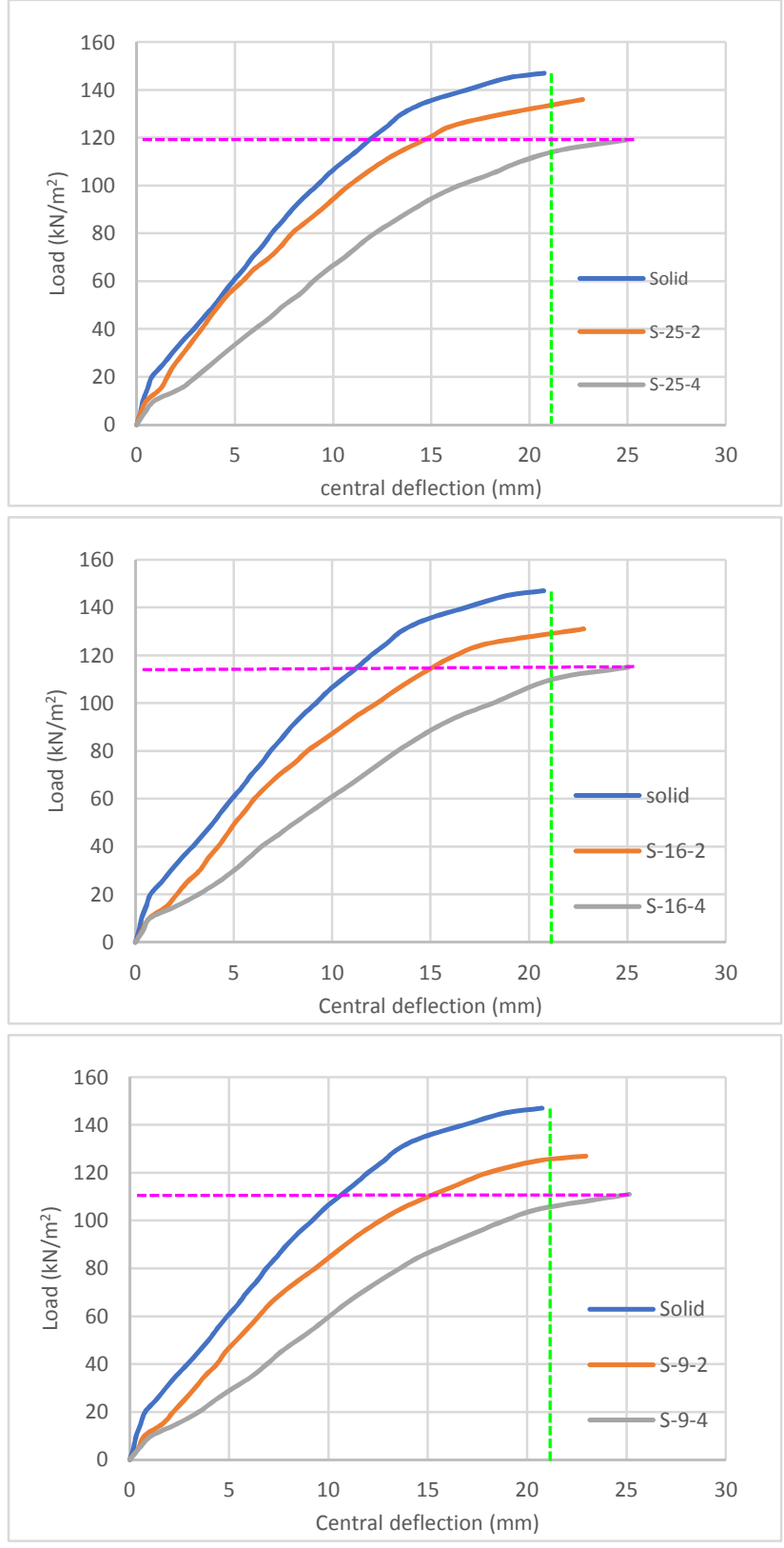

Figure 10: Effect of cavity thickness on load-central deflection for slabs of Group 1 (Slabs with square cavities)
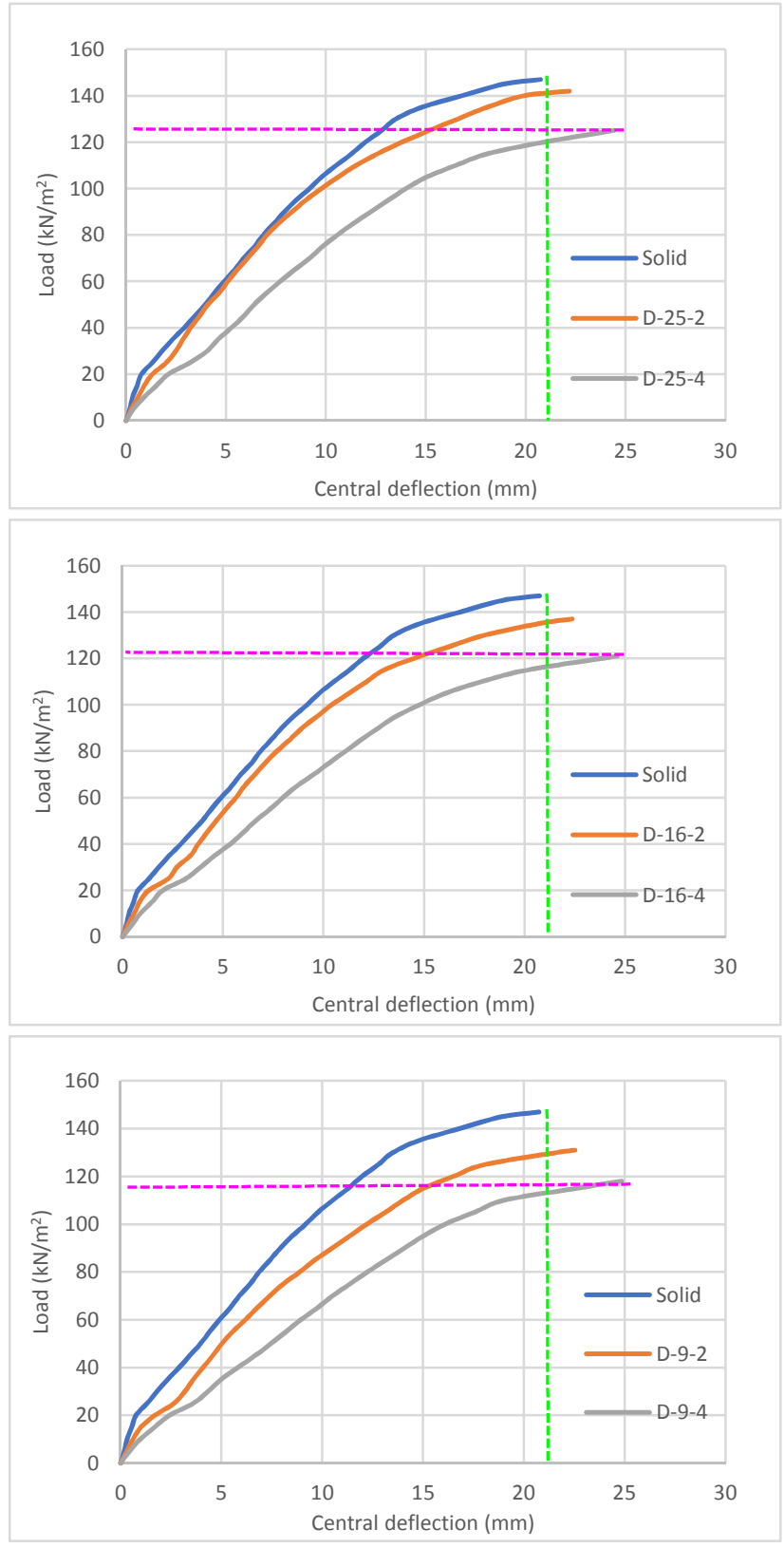

Figure 11: Effect of cavity thickness on load-central deflection for slabs of Group 2 (Slabs with diamond cavities) 

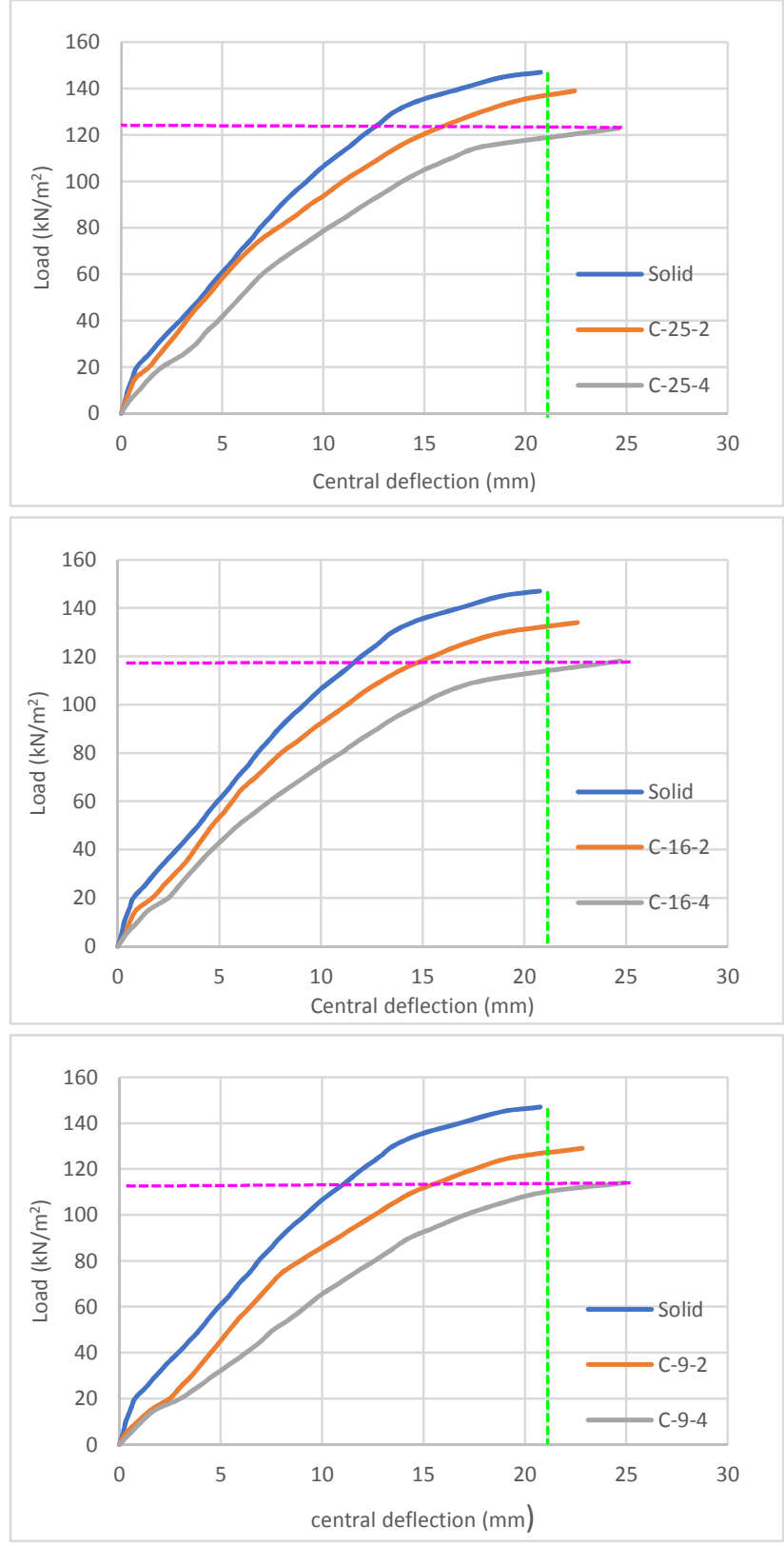

Figure 12: Effect of cavity thickness on load - central deflection for slabs of Group 3 (Slabs with circular cavities)
Table 4: Effect of cavity thickness on loads for slabs with constant cavity number

\begin{tabular}{|c|c|c|c|}
\hline & $\begin{array}{c}\text { Slab } \\
\text { models }\end{array}$ & $\begin{array}{c}\text { Load at same } \\
\text { deflection level } \\
\text { of ultimate load } \\
\text { of the solid slab } \\
\left(\mathrm{kN} / \mathrm{m}^{2}\right)\end{array}$ & $\begin{array}{c}\% \\
\text { decreasing } \\
\text { in load }\end{array}$ \\
\hline & Solid & 147 & - \\
\hline \multirow[t]{2}{*}{ Group 1} & $S-25-2$ & 132 & 10.20 \\
\hline & $S-25-4$ & 115 & 21.77 \\
\hline (Slabs & $S-16-2$ & 128 & 12.93 \\
\hline with & $S-16-4$ & 108 & 26.53 \\
\hline square & $S-9-2$ & 123 & 16.33 \\
\hline cavities) & $S-9-4$ & 103 & 29.93 \\
\hline \multirow[t]{2}{*}{ Group 2} & $D-25-2$ & 140 & 4.76 \\
\hline & $D-25-4$ & 120 & 18.37 \\
\hline (Slabs & $D-16-2$ & 135 & 8.16 \\
\hline with & $D-16-4$ & 117 & 20.41 \\
\hline diamond & $\mathrm{D}-9-2$ & 126 & 14.29 \\
\hline cavities) & $D-9-4$ & 113 & 23.13 \\
\hline \multirow[t]{2}{*}{ Group 3} & $C-25-2$ & 137 & 6.80 \\
\hline & $C-25-4$ & 120 & 18.37 \\
\hline (Slabs & $C-16-2$ & 131 & 10.88 \\
\hline with & $C-16-4$ & 113 & 23.13 \\
\hline circular & $\mathrm{C}-9-2$ & 127 & 13.61 \\
\hline cavities) & $C-9-4$ & 110 & 25.17 \\
\hline
\end{tabular}

\subsubsection{Effect of cavity shape on load-deflection behavior}

Figs. 13, 14 and 15 show the load-deflection curves for models of same number and thickness of cavities but with different shape. From these curves it can be concluded that the models of square cavities have the lowest ultimate load capacity and the highest ultimate deflection while the models of diamond cavities have the higher load capacity and lowest ultimate deflection.

Also, Table 6 shows the effect of cavity shape with constant number and thickness on the percentage decreasing in ultimate load and increasing the ultimate deflection compare with the reference model (solid slab).

Table 5: Effect of cavity thickness on deflection for slabs with constant cavity number

\begin{tabular}{|c|c|c|c|c|}
\hline $\begin{array}{c}\text { Shape of } \\
\text { cavities }\end{array}$ & $\begin{array}{c}\text { Number of } \\
\text { cavities }\end{array}$ & $\begin{array}{c}\text { Deflection of slabs } \\
\text { with 4 cm cavity } \\
\text { thickness }\end{array}$ & $\begin{array}{c}\text { Deflection of solid slab at } \\
\text { the same load level of slabs } \\
\text { with 4 cm cavity thickness }\end{array}$ & $\begin{array}{c}\text { Deflection of slabs of 2 cm cavity } \\
\text { thickness at the same load level of } \\
\text { slabs with 4 cm cavity thickness }\end{array}$ \\
\hline \multirow{3}{*}{ Square } & 25 & 24.94 & 12 & 14.6 \\
\cline { 2 - 5 } & 16 & 25.07 & 11.3 & 15 \\
\hline \multirow{3}{*}{ Diamond } & 9 & 25.14 & 11 & 15.5 \\
\cline { 2 - 5 } & 16 & 24.41 & 12.8 & 14.95 \\
\cline { 2 - 5 } & 9 & 24.62 & 11.5 & 15.6 \\
\hline \multirow{3}{*}{ Circle } & 25 & 24.85 & 12.5 & 16 \\
\cline { 2 - 5 } & 16 & 24.63 & 11.8 & 14.9 \\
\hline
\end{tabular}


Table 6: Effect of cavity shape with constant number and thickness on ultimate load and deflection

\begin{tabular}{|c|c|c|c|c|c|c|}
\hline 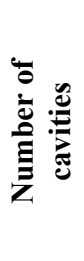 & 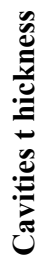 & 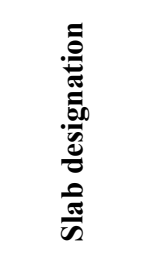 & 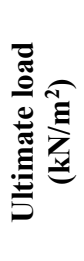 & 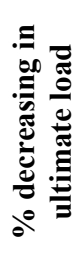 & 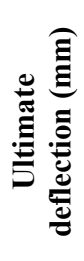 & 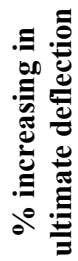 \\
\hline \multirow[t]{3}{*}{0} & \multirow[t]{2}{*}{-} & Solid & 147 & - & 20.75 & - \\
\hline & & $S-25-2$ & 136 & 7.48 & 22.71 & 9.45 \\
\hline & \multirow[t]{3}{*}{2} & $D-25-2$ & 142 & 3.40 & 22.19 & 6.94 \\
\hline \multirow{6}{*}{25} & & $C-25-2$ & 139 & 5.44 & 22.42 & 8.05 \\
\hline & & $S-25-4$ & 119 & 19.05 & 24.94 & 20.19 \\
\hline & \multirow[t]{3}{*}{4} & $D-25-4$ & 125 & 14.97 & 24.41 & 17.64 \\
\hline & & $C-24-4$ & 123 & 16.33 & 24.63 & 18.70 \\
\hline & & $S-16-2$ & 131 & 10.88 & 22.78 & 9.78 \\
\hline & \multirow[t]{3}{*}{2} & $D-16-2$ & 137 & 6.80 & 22.37 & 7.81 \\
\hline \multirow{6}{*}{16} & & $C-16-2$ & 134 & 8.84 & 22.61 & 8.96 \\
\hline & & $S-16-4$ & 115 & 21.77 & 25.07 & 20.82 \\
\hline & \multirow[t]{3}{*}{4} & $D-16-4$ & 121 & 17.69 & 24.62 & 18.65 \\
\hline & & $C-16-4$ & 118 & 19.73 & 24.75 & 19.28 \\
\hline & & $S-9-2$ & 127 & 13.61 & 22.96 & 10.65 \\
\hline & 2 & $D-9-2$ & 131 & 10.88 & 22.54 & 8.63 \\
\hline \multirow{4}{*}{9} & & $C-9-2$ & 129 & 12.24 & 22.83 & 10.02 \\
\hline & \multirow{3}{*}{4} & $S-9-4$ & 111 & 24.49 & 25.14 & 21.16 \\
\hline & & $D-9-4$ & 118 & 19.73 & 24.85 & 19.76 \\
\hline & & $C-9-4$ & 114 & 22.45 & 24.94 & 20.19 \\
\hline
\end{tabular}

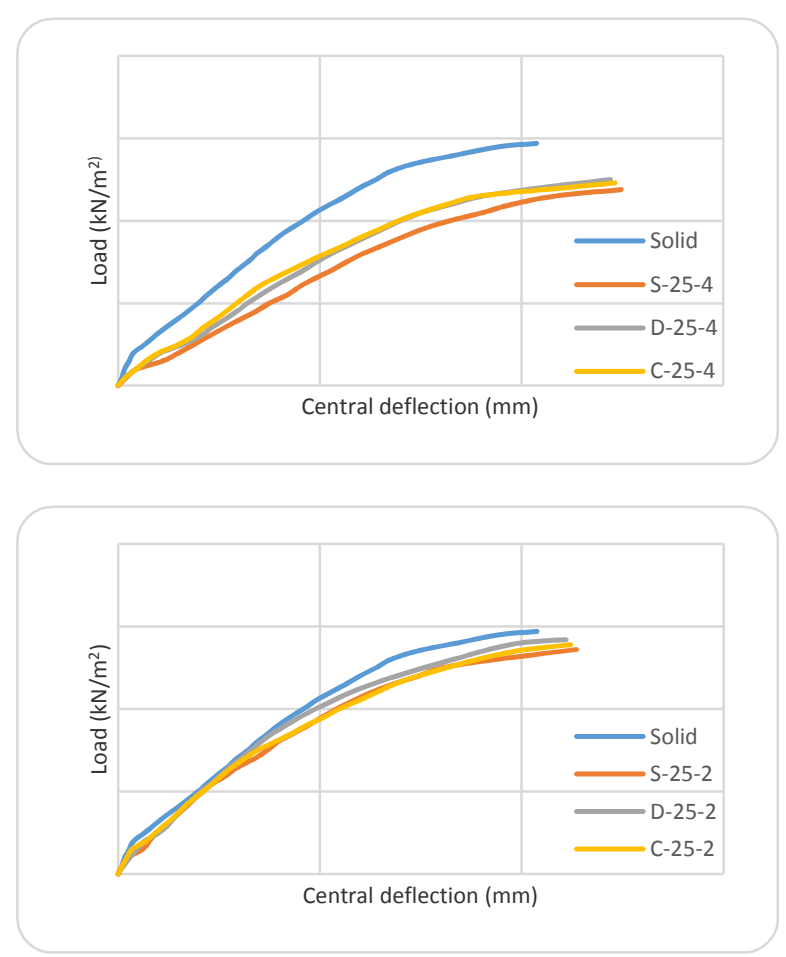

Figure 13: Effect of cavity shape with constant number (25) on load-central deflection response

\subsubsection{Effect of cavity number on load - central deflection behavior}

Generally, it was observed that the ultimate deflection of the slab models which contain a larger number of cavities were smaller than that of a less number. The reason of that is probably the increasing of concrete ribs which occurred when the number of cavities was increased, where it caused an increasing in the stiffness of the specimens. Figs. 16, 17 and 18 show the load-central deflection curves of slab models with different number of cavities. Table 7 shows the effect of number of cavities on ultimate loads and central deflection as correspond with the reference model (solid slab).

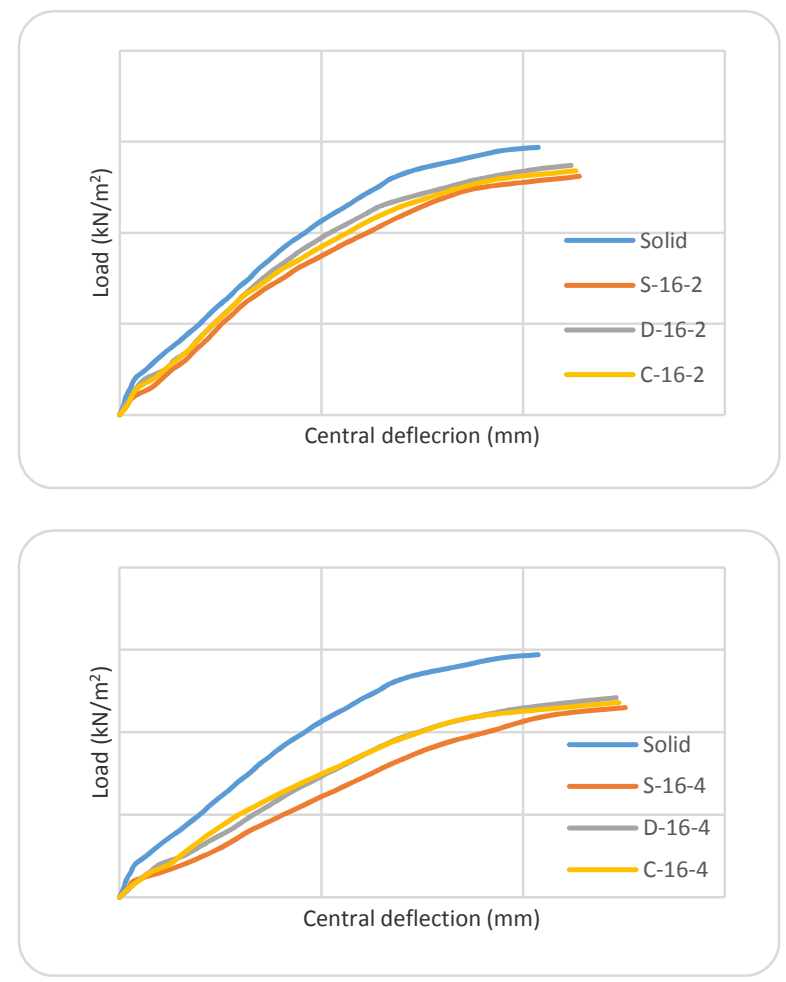

Figure 14: Effect of cavity shape with constant number (16) on load - central deflection response

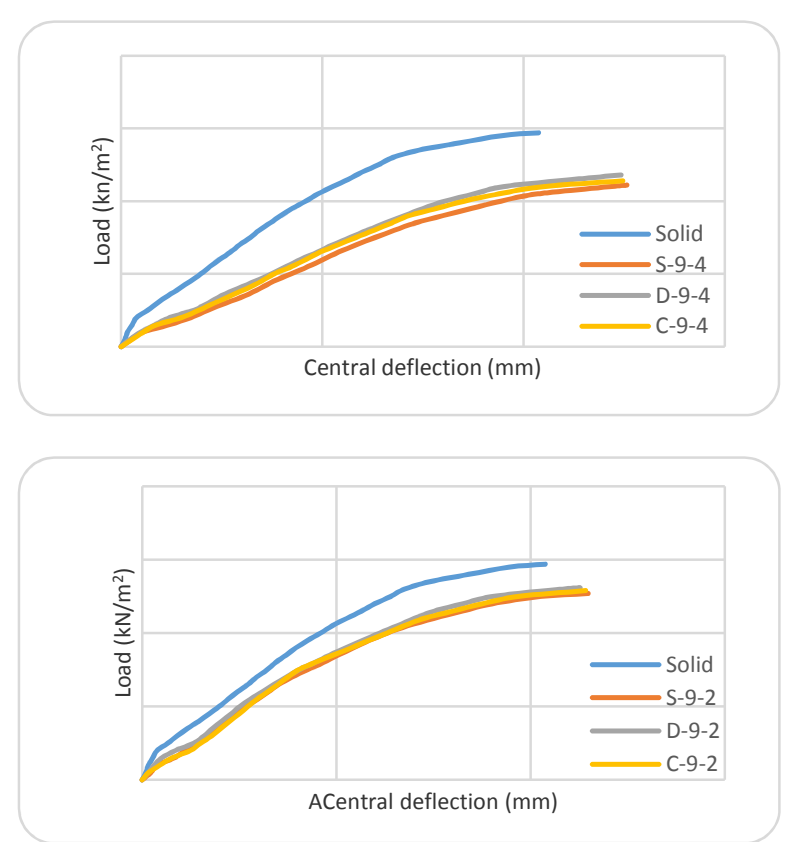


Figure 15: Effect of cavity shape with constant number (9) on load - central deflection response
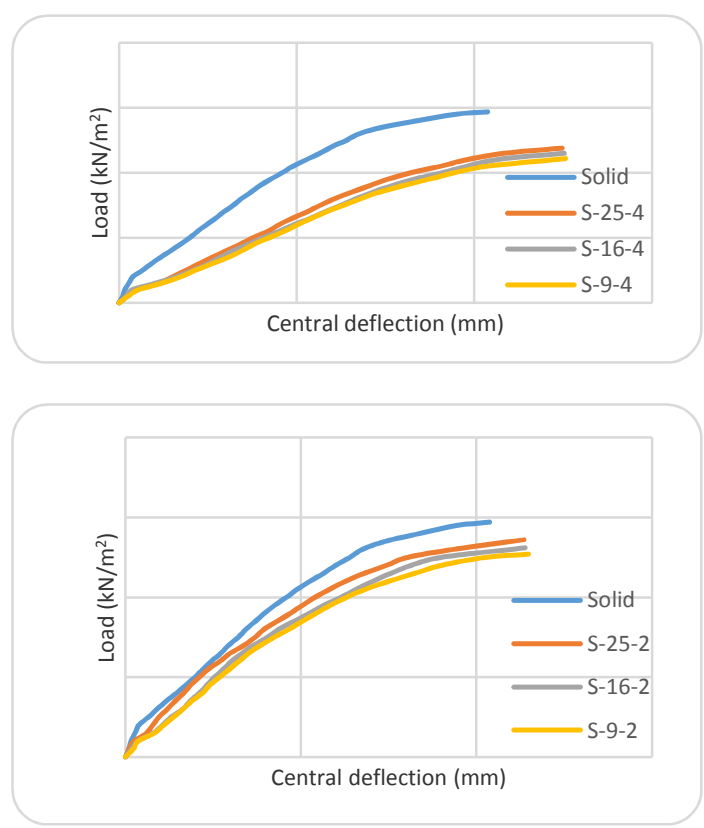

Figure 16: Effect of number of cavities with square shape on load - central deflection response

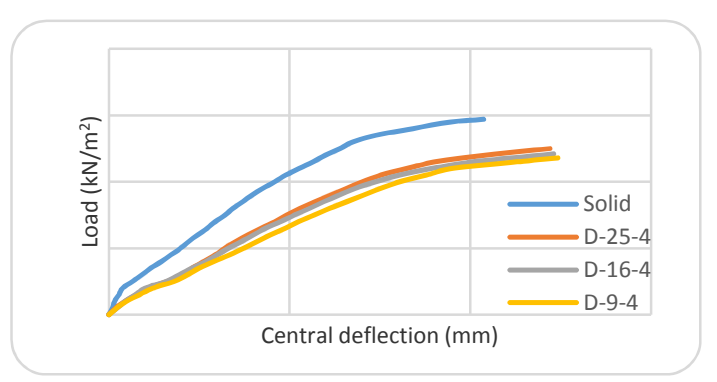

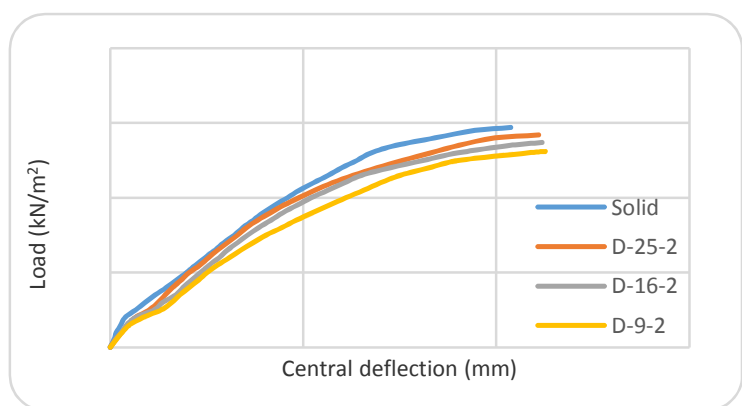

Figure 17: Effect of number of cavities with diamond shape on load - central deflection response
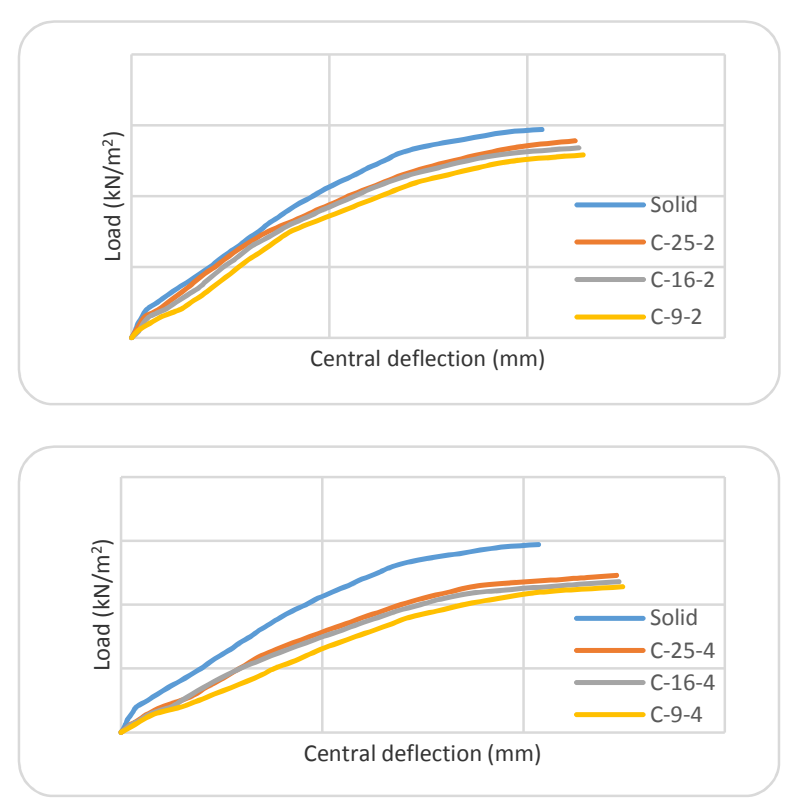

Figure 18: Effect of number of cavities with circular shape on load - central deflection response

Table. 7: Load value of all voided slabs at the ultimate deflection of solid slab

\begin{tabular}{|c|c|c|c|c|c|c|}
\hline $\begin{array}{c}\text { Cavities } \\
\text { shape }\end{array}$ & $\begin{array}{l}\text { Cavities } \\
\text { thickness }\end{array}$ & $\begin{array}{c}\text { Slab } \\
\text { specimens }\end{array}$ & $\begin{array}{l}\text { Ultimate } \\
\text { load }\left(w_{u}\right)\end{array}$ & $\begin{array}{c}\text { \% decreasing } \\
\text { in ultimate } \\
\text { load }\end{array}$ & $\begin{array}{c}\begin{array}{c}\text { Ultimate } \\
\text { deflection } \\
(\mathrm{mm})\end{array} \\
\end{array}$ & $\begin{array}{l}\% \text { increasing in } \\
\text { ultimate deflection }\end{array}$ \\
\hline \multirow{8}{*}{ Square } & - & Solid & 147 & - & & \\
\hline & \multirow{3}{*}{2} & $S-25-2$ & 136 & 7.48 & 22.71 & 9.45 \\
\hline & & $S-16-2$ & 131 & 10.88 & 22.78 & 9.78 \\
\hline & & $S-9-2$ & 127 & 13.61 & 22.96 & 10.65 \\
\hline & \multirow{4}{*}{4} & $S-25-4$ & 119 & 19.05 & 24.94 & 20.19 \\
\hline & & $S-16-4$ & 115 & 21.77 & 25.07 & 20.82 \\
\hline & & $S-9-4$ & 111 & 24.49 & 25.14 & 21.16 \\
\hline & & $D-25-2$ & 142 & 3.40 & 22.19 & 6.94 \\
\hline \multirow{5}{*}{ Diamond } & \multirow[t]{3}{*}{2} & $D-16-2$ & 137 & 6.80 & 22.37 & 7.81 \\
\hline & & $D-9-2$ & 131 & 10.88 & 22.54 & 8.63 \\
\hline & & $D-25-4$ & 125 & 14.97 & 24.41 & 17.64 \\
\hline & \multirow[t]{3}{*}{4} & $D-16-4$ & 121 & 17.69 & 24.62 & 18.65 \\
\hline & & $D-9-4$ & 118 & 19.73 & 24.85 & 19.76 \\
\hline \multirow{6}{*}{ Circle } & & $C-25-2$ & 139 & 5.44 & 22.42 & 8.05 \\
\hline & \multirow[t]{3}{*}{2} & $C-16-2$ & 134 & 8.84 & 22.61 & 8.96 \\
\hline & & $C-9-2$ & 129 & 12.24 & 22.83 & 10.02 \\
\hline & & $C-25-4$ & 123 & 16.33 & 24.63 & 18.70 \\
\hline & \multirow[t]{2}{*}{4} & $C-16-4$ & 118 & 19.73 & 24.75 & 19.28 \\
\hline & & $\mathrm{C}-9-4$ & 114 & 22.45 & 24.94 & 20.19 \\
\hline
\end{tabular}




\section{Conclusions}

Based on the results the following points can be concluded:

1. The percentage of weight reduction $(14.0 \%)$ for models of $(2 \mathrm{~cm})$ cavities thickness, and in this case the ultimate load capacity is reduced with range (3.40 to 13.61$) \%$. While the percentage weight reduction $(28.0 \%)$ for models of $(4 \mathrm{~cm})$ cavities thickness, the ultimate load capacity is reduced with range (14.97 to 24.29$) \%$.

2. The models of $(2 \mathrm{~cm})$ thickness of cavities have higher ultimate load capacity and lower ultimate deflection.

3. The models with cavities of diamond shape have the highest ultimate load capacity and the lowest ultimate deflection when compared with other groups (circular or square cavities), while the models with cavities of square shape have the lowest ultimate load capacity and highest ultimate deflection.

4. The slab models of larger number of cavities have the higher ultimate load capacity and lower ultimate deflection than the models of lower number of cavities.

\section{References}

[1] ACI 318M-14, "Building Code Requirements for Structural Concrete and Commentary", 2014.

[2] ANSYS Mechanical APDL 17.1 Help.
[3] Bum-Yean Cho, Hyung-Jun Kim, Kyung-Hoon Park and Heung-Youl Kim, "Experimental Study on Fire Resistance Performance of a Hollow Slab Using a Lightweight Hollow Sphere", 10th International Conference of the International Institute for Infrastructure Resilience and Reconstruction (I3R2), pp. 98-104, 2014.

[4] D. L. Logan. (2012). A first course in the FE method, fifth edition. United States of America: Global Engineering: Christopher M. Shortt.

[5] F. A. Tavarez., "Simulation of behaviour of composite grid reinforced concrete beams using explicit Finite flement method. Wisconsin" M. Sc. Thesis, University of Wisconsin-Madison, 2001.

[6] Joo-Hong Chung, Hyung-Suk Jung, Baek-il Bae, Chang-Sik Choi, and Hyun-Ki Choi, "Two-Way Flexural Behavior of Donut-Type Voided Slabs" International Journal of Concrete Structures and Materials, ISSN 19760485 / e ISSN 2234-1315, 2018

[7] M. Osman, H. Marzouk, and S. Helmy "Behavior of High-Strength Lightweight Concrete Slabs under Punching Loads" Aci Structural Journal, no. 97-S53, pp. 492-498,2016.

[8] Nanang Gunawan Wariyatno, Yanuar Haryanto and Gathot Heri Sudibyo, "Flexural behavior of precast hollow core slab using PVC pipe and Styrofoam with different reinforcement”, Procedia Engineering, vol. 171, pp. 909916, 2017.

[9] Rafal Szydlowki, Malgorzata Mieszcakb, "Study of application of lightweight aggregate concrete to construct post-tensioned long-span slabs" Procedia Engineering, vol. 172, pp.1077 - 1085, 2017.

$$
\begin{aligned}
& \text { در اسة عددية حول تصرف و أداء البلاطات الخرسانبة المسلحة العاملة باتجاهين بوجود فر اغات } \\
& \text { بمقاسات و أشكال مختلفة } \\
& \text { رند طارق كنعان 1،*، علحي حسين علي آل- أحد } 2
\end{aligned}
$$

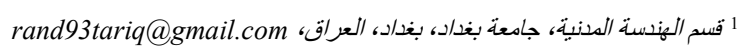

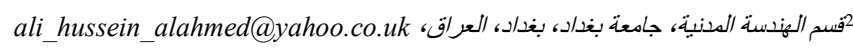

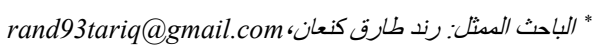

$$
\begin{aligned}
& \text { شن } 31 \text { آذار } 2019 \\
& \text { الخلاصة - يدرس هذا البحث أداء أو سلوك البلاطات الخرسانية المسلحة ثنائية الاتجاه و المحتويةعلى فجو ات مختلفة القياسات و الاشكال عدديا تحت تأثنير }
\end{aligned}
$$

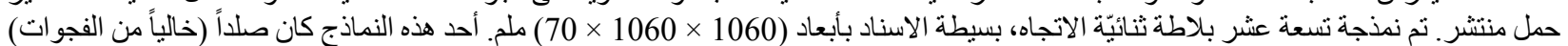

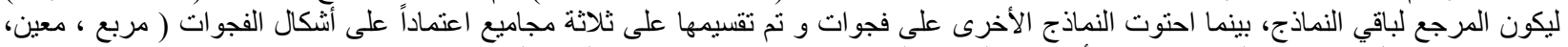

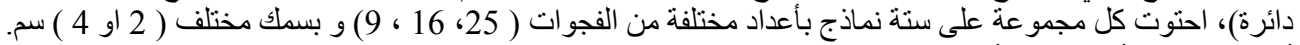

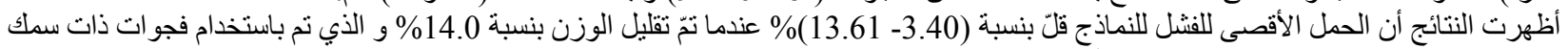

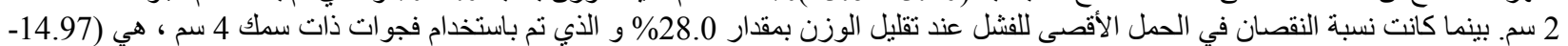

$$
\begin{aligned}
& \text { \%(24.49 } \\
& \text { الكلمات الرئيسية ــ فجوات، السقوف المجوفة، قطع الفلين، السقوف ثنائية الاتجاه، تقليل الوزن. }
\end{aligned}
$$

